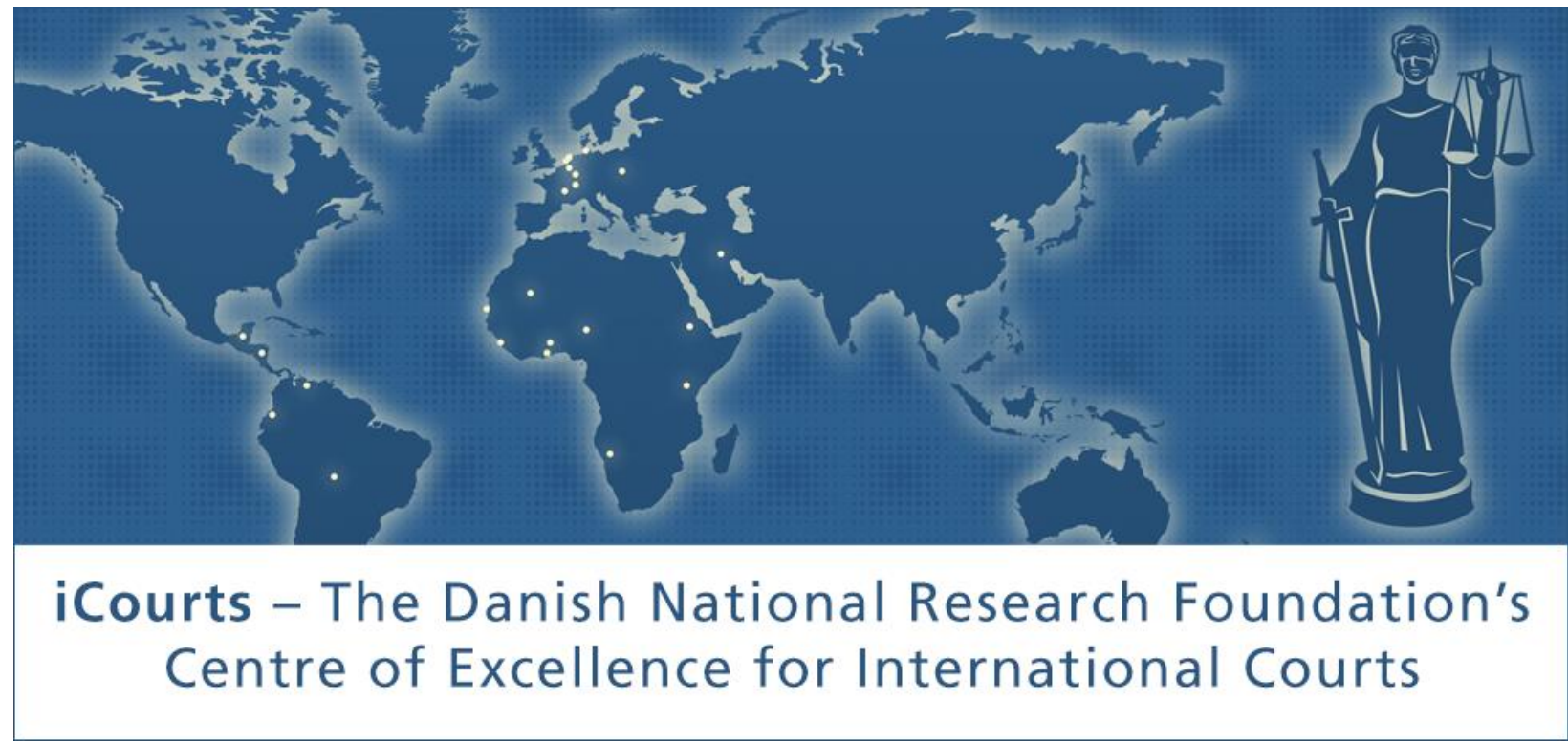

iCourts Working Paper Series, No. 32, 2015

\title{
Sub-regional Courts in Africa: Litigating the Hybrid Right to Freedom of Movement
}

\section{Laurence R. Helfer}

iCourts - The Danish National Research Foundation's

Centre of Excellence for International Courts 


\begin{abstract}
:
Human rights attorneys and civil society groups in Africa have recently focused their advocacy efforts on sub-regional courts associated with economic integration communities in East, West and Southern Africa. The East African Court of Justice (EACJ), the Court of Justice of the Economic Community of West African States (ECOWAS), and the Tribunal of the Southern African Development Community (SADC) have received few suits challenging trade restrictions and other barriers to sub-regional integration. Instead, and surprisingly, the courts' dockets are dominated by complaints alleging violations of international human rights law.

This article offers the first analysis of EACJ, ECOWAS Court and SADC Tribunal decisions concerning the free movement of persons. Freedom of movement is a hybrid legal right. It is protected in the African Charter on Human and Peoples' Rights and in other human rights instruments, but it is also a central pillar of all regional integration systems. Free movement case law thus offers a revealing lens through which to examine how African sub-regional courts decide which litigants have access to justice, interpret international legal norms, and fashion the remedies awarded to successful complainants.
\end{abstract}

KEYWORDS: free movement, international court, Africa, ECOWAS, East African Court of Justice, SADC, human rights, regional integration, African Charter

Laurence R. Helfer is professor of Law at Duke University, United States of America, and a permanent visiting professor at the Centre of Excellence for International Courts (iCourts), University of Copenhagen, Denmark

E-mail: helfer@law.duke.edu 
This research is funded by the Danish National Research Foundation Grant no. DNRF105.

iCourts - Centre of Excellence for International Courts - focuses on the ever-growing role of international courts, their place in a globalizing legal order, and their impact on politics and society at large. To understand these crucial and contemporary interplays of law, politics, and society, iCourts hosts a set of deeply integrated interdisciplinary research projects on the causes and consequences of the proliferation of international courts.

iCourts opened in March 2012. The centre is funded by a large grant from the Danish National Research Foundation (for the period 2012-18). 


\section{INTRODUCTION}

International human rights litigation in Africa is evolving in ways that few could have foreseen only a decade ago. Human rights attorneys and civil society groups now focus much of their advocacy efforts not on the judicial and quasi-judicial bodies of the African Charter human rights system ${ }^{1}$ the African Court and Commission on Human and Peoples' Rights - but on sub-regional courts associated with economic integration communities in West, East and Southern Africa. The dockets of these courts contain few cases involving tariffs, trade barriers and other integration law issues. Instead, they are dominated by suits alleging violations of international human rights law, suits to which the judges have responded by issuing high-profile rulings against African governments.

Consider a few recent examples. In 2015, the East African Court of Justice (EACJ) held that Burundi's media law, which bars journalists from reporting on certain topics and requires them to reveal their sources to the government, violates the East African Community (EAC) Treaty. ${ }^{2}$ In 2012, the Court of Justice of the Economic Community of West African States (ECOWAS) ruled against Nigeria for failing to regulate multinational companies whose oil extraction activities have degraded the Niger Delta. ${ }^{3}$ And in 2008, the Tribunal of the Southern African Development Community (SADC) issued an audacious judgment in favor of a group of white farmers who had challenged Zimbabwe's post-colonial land redistribution policies. ${ }^{4}$ These and other high-profile rulings are encouraging the filing of new human rights suits, including suits from attorneys who can choose whether to litigate before a national court, a sub-regional court or one of the African Charter bodies.

The sub-regional courts in West, East and Southern Africa share a number of similarities. They were not created to hear cases alleging violations of international human rights law. Instead, they were tasked with improving the enforcement of each integration project's founding legal instruments. For the EACJ and the SADC Tribunal, the shift to human rights occurred via expansive interpretations of the integration treaties' principles and objectives clauses adopted by sub-regional judges in response to advocacy by law societies and private litigants. ${ }^{5}$ In West Africa, the expansion into human rights resulted from an extrajudicial advocacy campaign by international

\footnotetext{
${ }^{1}$ African (Banjul) Charter on Human and Peoples' Rights, June 27, 1981, 1520 U.N.T.S. 217, 21 I.L.M. 58 (1982).

${ }^{2}$ Burundi Journalists Union v. Attorney Gen. of Burundi, Ref. No. 7 of 2013 (May 15, 2015), http://eacj.org/wpcontent/uploads/2015/05/Reference-No.7-of-2013-Final-15th-May-2c-2015-Very-Final.pdf. The EACJ held that the EAC Treaty implicitly incorporates a right to freedom of expression. Id., paras. 75-83.

${ }^{3}$ Socio-Economic Rights and Accountability Project (SERAP) v. Nigeria, Case No. ECW/CCJ/APP/08/09, Judgment, (Dec. 14, 2012).

${ }^{4}$ Campbell and Others v. Zimbabwe (Merits), Case No. SADC (T) 2/2007 (Nov. 28, 2008) [hereinafter Campbell] (holding that Zimbabwe had denied the farmers access to justice, failed to pay them fair compensation, and discriminated against them on the basis of race).

${ }^{5}$ See James Gathii, Mission Creep or a Search for Relevance: The East African Court of Justice's Human Rights Strategy, 24 DuKE J. COMP. \& INT’L L. 249, 250 (2014) [hereinafter Gathii, Mission Creep].
} 
judges, civil society groups, and Community officials to convince member states to broaden the ECOWAS Court's jurisdiction. ${ }^{6}$

All three sub-regional courts also experienced significant political backlashes after they began to issue judgments against African governments. In SADC, the backlash was severe, resulting in the indefinite suspension of the Tribunal. In East and West Africa, both sub-regional courts survived. In ECOWAS, judicial reform proposals that were barely disguised rebukes of sub-regional judges were narrowly defeated. In the EAC, member states created a new appellate division, staffed it with more conservative judges, and narrowed the EACJ's jurisdiction. ${ }^{7}$

The legacy of the events described above for sub-regional human rights litigation in Africa is evident in each of the three topics examined in this symposium-access, interpretation and remedies. First and perhaps most striking is that human rights complainants in West and East Africa need not exhaust domestic remedies, unlike those litigating in the African, American and European systems. This enables individuals and NGOs to bypass national judges and administrative agencies and go directly to the sub-regional courts. Such direct access often results in legally binding judgments against governments in far less time-sometimes just a few monthsthan does litigating in national courts or before the African Court or Commission. Yet at the same time, ECOWAS and EACJ judges strictly adhere to limitations periods and other admissibility requirements that may make it difficult for private litigants to access the courts.

Second, none of the integration projects includes a catalogue of protected rights and freedoms. This gives sub-regional judges broad discretion to determine which rights are justiciable. The courts' decisions have drawn upon a variety of sources, primarily the African Charter and the human rights clauses of sub-regional treaties and protocols, but also on global conventions, customary international law and nonbinding norms. This potpourri of legal sources sometimes leads to interpretive choices that differ from those of human rights courts in Europe, the Americas and Africa. This divergence is not unidirectional, however. Although some sub-regional rulings are bold and expansive, others are quite deferential to a state's legal arguments and to the political implications of a ruling against the government.

A third distinctive feature of sub-regional human rights litigation relates to remedies. The EACJ can declare violations of the law, order injunctive relief and impose costs. It cannot, however, award damages for legal violations. ${ }^{8}$ The situation in West Africa is quite different. ECOWAS judges can issue a full panoply of remedies to successful applicants, but they generally limit relief to a declaration that a state has violated an applicant's rights, sometimes accompanied by a modest

\footnotetext{
${ }^{6}$ See Karen J. Alter, Laurence R. Helfer and Jacqueline McAllister, A New International Human Rights Court for West Africa: The ECOWAS Community Court of Justice, 108 AM. J. INT'L L. 737, 737-39 (2013).

${ }^{7}$ See Karen J. Alter, James T. Gathii and Laurence R. Helfer, Backlash Against International Courts in West, East and Southern Africa: Causes and Consequences, ICOURTS WORKING PAPER SERIES, No. 21 (May 12, 2015), http://ssrn.com/abstract=2591837. In August 2014, SADC member states adopted a new protocol that strips the SADC Tribunal of private litigant access. The Protocol has yet to enter into force and is opposed by human rights NGOs in Southern Africa. In the meanwhile, the Tribunal remains suspended. Id.

${ }^{8}$ Ndorimana v. Attorney Gen, of Burundi, Ref. No. 2 of 2013, Judgment, First Instance Division (Nov. 28, 2014).
} 
damage award. Orders directing a government to carry out specific measures are much less common. The SADC Tribunal arguably provided the boldest remedies of the three courts in the white farmers' cases - including sanctioning Zimbabwe for ignoring its prior decisions. But the Tribunal's suspension in 2011 - partly in reaction to those same bold remedies - means that it has issued only a handful of decisions.

Cases involving freedom of movement offer an especially revealing lens through which to examine the African sub-regional courts' distinctive approaches to access, interpretation and remedies. Freedom of movement is a hybrid legal right. It is protected in the African Charter ${ }^{9}$ and in other human rights instruments, but it is also a central pillar of all regional integration systems. Legal instruments adopted by EAC, ECOWAS and SADC each include provisions concerning the free movement of Community citizens among their respective member states. ${ }^{10}$

Unfortunately, these overlapping legal commitments are often honored in the breach. African governments regularly close international borders for security and political reasons or refuse entry to foreign nationals on those grounds. ${ }^{11}$ Unofficial barriers to cross-border travel—such as roadblocks, bureaucratic red tape, and graft by customs officials - are also commonplace. ${ }^{12}$ Free movement violations thus implicate an important obstacle to sub-regional integration that arises at the intersection of human rights and economic law. Yet suits challenging such violations also raise fraught political issues for international judges, whose rulings in favor of private litigants may be viewed by governments as challenging a fundamental attribute of sovereignty - the power of a state to control who enters its territory.

The sub-regional courts' free movement case law thus sheds light on the challenges faced by private litigants and attorneys seeking access to these courts, the interpretive choices made by sub-regional judges, and the remedies awarded to successful applicants. The cases also illuminate the wider political and social contexts in which ECOWAS, EAC, and SADC judges operate. Section II reviews these free movement decisions, several of which have not previously been analyzed by

\footnotetext{
${ }^{9}$ Article 12 of the African Charter provides in relevant part:

2. Every individual shall have the right to leave any country including his own, and to return to his country. This right may only be subject to restrictions, provided for by law for the protection of national security, law and order, public health or morality. ...

4. A non-national legally admitted in a territory of a State Party to the present Charter, may only be expelled from it by virtue of a decision taken in accordance with the law.

${ }^{10}$ See, e.g., Protocol A/P.1/5/79 Relating to Free Movement of Persons, Residence and Establishment, Article 3, May 29, 1979 [hereinafter ECOWAS Free Movement Protocol]; Protocol on the Establishment of the East African Community Common Market, Article 7, Nov. 20, 2009 [hereinafter EAC Common Market Protocol]; Treaty of the Southern African Development Community, Article 5(2)(d), Aug. 17, 1992.

11 The ECOWAS Court's first case involved a challenge by a private goods trader to Nigeria's closure of the border with Benin. The Court, whose jurisdiction at the time was limited to interstate cases, dismissed the suit. Afolabi v. Nigeria, Case No. ECW/CCJ/APP/01/03, Judgment, paras. 55-58 (Apr. 27, 2004). The judges then began an ultimately successful campaign to lobby the member states to give private litigants access to the Court. See Alter, Helfer \& McAllister, supra note _, at 750-53.

${ }^{12}$ Nat'l Ass'n of Nigerian Traders, Sovereignty, Supranationality and Trade: The Case of ECOWAS Laws, 2 ECOWAS VANGUARD at 7 (Feb. 2013) [hereinafter Sovereignty, Supranationality and Trade] (copy on file with author).
} 
commentators. Section III compares and contrasts the reasoning and outcomes in these cases, focusing on the three topics examined in this symposium-access, interpretation and remedies. Section IV briefly concludes, identifying avenues for future research.

\section{Litigating THE Right TO FREEDOM OF MOVEMENT IN SADC, ECOWAS AND THE EAC}

In recent years, sub-regional courts in Southern, West, and East Africa have adjudicated several cases challenging restrictions on freedom of movement. This section reviews these decisions chronologically. It begins with the 2010 admissibility ruling of the SADC Tribunal, then turns to 2012 and 2013 judgments of the ECOWAS Court, and concludes with three decisions of the EACJ First Instance Division from 2013, 2014 and 2015, two of which find violations of the right to freedom of movement.

\section{A. The SADC Tribunal}

In United Republic of Tanzania v. Cimexpan (Mauritius) LTD and Others, ${ }^{13}$ Ajaye Jogoo, a resident alien in Tanzania and the director of a Mauritian investment company, challenged his deportation following the cancellation of a joint venture contract with the government of Zanzibar. Jogoo claimed that his family, who remained in Tanzania after his deportation, was assaulted by armed men. When Jogoo attempted to return to the country, Tanzanian immigration officials jailed him for a week and allegedly tortured him before deporting him again.

Jogoo filed suit against Tanzania with the SADC Tribunal, seeking to rescind the deportation order. ${ }^{14}$ The state filed a preliminary objection arguing that the Tribunal lacked jurisdiction, the applicant had not exhausted local remedies, and the "admission and expulsion of aliens rested[] within [the government's] powers" and was not subject to judicial review. ${ }^{15}$ After rejecting the jurisdictional objection as contrary to the SADC Tribunal Protocol, ${ }^{16}$ the judges agreed that Jogoo had not exhausted domestic remedies because, even from outside Tanzania, he could have hired an attorney in the country "to challenge by judicial review the deportation order made against him, if he had so wished."17

\footnotetext{
${ }^{13}$ Case No. SADC (T) 01/2009 (June 11, 2010) [hereinafter Cimexpan].

${ }^{14}$ Tanzania is a member of both SADC and the EAC. It is unclear why Jogoo filed suit before the SADC Tribunal rather than the EACJ, especially since the latter court does not require exhaustion of domestic remedies. One possibility is that Jogoo, as a national of another SADC member state (Mauritius), may have believed he had a stronger legal basis for objecting to his deportation. This does not explain, however, why Jogoo would choose the SADC Tribunal as his preferred venue for a suit alleging human rights abuses such as torture. Although timing of the litigation is unclear, if Jogoo's alleged mistreatment occurred prior to the Katabazi v. Sec'y Gen. of the E. African Cmty., Ref. No. 1 of 2007 (Nov. 1, 2007) - the first EACJ decision asserting the authority to hear human rights complaints couched as violations of the EAC Treaty - he may have concluded the EACJ would dismiss a suit alleging human rights abuses by Tanzanian officials.

${ }^{15}$ Cimexpan, supra note _, at 6.

${ }^{16}$ Article 14 of the Protocol provides that the Tribunal "shall have jurisdiction over all disputes and all applications referred to it in accordance with the [SADC] Treaty and this Protocol which relate to ... the interpretation and application of the Treaty." Protocol on the Tribunal and Rules thereof (2000) [hereinafter SADC Tribunal Protocol], http://www.sadc.int/files/1413/5292/8369/Protocol_on_the_Tribunal_and_Rules_thereof2000.pdf.

${ }^{17}$ Cimexpan, supra note _, at 6.
} 
The Tribunal then considered the legality of the expulsion order. Although agreeing with the government that "the right to admit or to expel an alien remains squarely within the preserve of [Tanzania's] sovereignty," the judges conditioned the exercise of this discretion upon "the observance of minimum human rights standards[] for the treatment of aliens." 18 These minimum standards, the Tribunal reasoned, are found in "the United Nations General Assembly Declaration on the Human Rights of Individuals Who Are Not Nationals of the Country in which They Live, Resolution 40/144 (1985); read together with the Universal Declaration of Human Rights, and other international instruments." 19 More specifically, the standards "include non-discrimination on grounds of race, the prohibition of torture and of inhuman or degrading treatment or punishment, and the right to a fair trial." 20 However, because Jogoo failed to offer any evidence to support his allegations of torture or mistreatment by Tanzanian immigration authorities, his deportation "did not constitute an international delinquency.",21

Scholars of regional integration may find the reasoning in Cimexpan puzzling, but the decision must be viewed in light of the weak legal protection of free movement in the sub-region. The 1992 SADC Treaty includes only a vague promise to "develop policies aimed at the progressive elimination of obstacles to the free movement of . . the peoples of the Region." 22 Not until 2005 did the member states adopt a Protocol to "facilitate" the movement of individuals, and even that unambitious legal instrument has not yet entered into force. ${ }^{23}$

Seen from this perspective, the Tribunal's conclusion that international human rights law provides some protection to alien deportees is quite progressive. The judges had previously claimed the authority to hear human rights suits as part of their mandate to adjudicate violations of the SADC Treaty. ${ }^{24}$ But the Cimexpan decision correctly notes that human rights law imposes few constraints on the expulsion of non-nationals. Indeed, the judges cite only nonbinding declarations and scholarly writings to support the conclusion that aliens have protection against abuses such as torture and racial discrimination. In light of Jogoo's failure to exhaust domestic remedies and inability to produce evidence supporting his alleged mistreatment, a ruling in favor of the

\footnotetext{
${ }^{18}$ Id. at 8.

${ }^{19}$ Id. at 7. The reference to "other international instruments" is likely to Article 13 of the International Covenant on Civil and Political Rights, cited earlier in the decision, which provides that "[a]n alien lawfully in the territory of a State Party to the present Covenant may be expelled therefrom only in pursuance of a decision reached in accordance with law and shall, except where compelling reasons of national security otherwise require, be allowed to submit the reasons against his expulsion and to have his case reviewed by . . . [a] competent authority . . .." Id. at 6 (quoting JOHN DUgARD, TERritory AND InTERnAtional LAW: A SOUTH AFRICAN PERSPECTIVE 298 (3d ed. 2005) [hereinafter Dugard, Territory]).

${ }^{20}$ Cimexpan, supra note _, at 7 (quoting Dugard, Territory).

${ }^{21}$ Id. at 8.

${ }^{22}$ SADC Treaty, supra note __, Article 5(2)(d).

${ }^{23}$ [SADC] Protocol on Facilitation of Movement of Persons, Aug. 18, 2005 (not yet in force). Only five SADC member states have ratified the Protocol, fewer than the nine required for its entry into force. Civil society groups recently launched a campaign to secure additional ratifications. Chandapiwa Baputaki, SADC-NGO to Launch Free Movement of Persons Campaign, MMEGI OnLine (Botswana) (July 7, 2015), http://www.mmegi.bw/index.php?sid=1\&aid=3660\&dir=2010/July/Friday16\#sthash.2CtXYJQ7.dpuf.

${ }^{24}$ Campbell, supra note _, at 34.
} 
government seems entirely appropriate. Nevertheless, by addressing the merits of the legal issue in dictum, the judges laid a foundation upon which they might have built additional legal protections for the freedom of movement had the Tribunal not been suspended.

\section{B. The ECOWAS Court}

In April 2004 Femi Falana and Waidi Moustapha, respectively the President and Vice President of the West African Bar Association, attempted to travel overland from Nigeria to Togo for meetings of the Association. At the Nigerian border, police, customs and immigration officials stopped the two men and blocked the road but eventually allowed them to enter Benin. The officials also allegedly harassed and attempted to extort money from other travelers. At the Togolese border, Falana and Moustapha were refused entry on the grounds that Togo "was holding its presidential election and the order was to close to the border." 25 Officials detained the two men until after the election, at which point "their assignment in Togo was not possible to be carried out.",26

Falana and Moustapha filed suit with the ECOWAS Court in October 2007, alleging violations of the right to freedom of movement guaranteed by the ECOWAS Free Movement Protocol and the African Charter. ${ }^{27}$ They asked the Court to declare that the member states "are under an obligation to remove all checkpoints, toll-gates, and obstacles to free movement" and to issue an order mandating their removal. ${ }^{28}$ In response, the states sought to dismiss the complaint on two jurisdictional grounds - first, that the 2005 Supplementary Protocol ${ }^{29}$ granting the ECOWAS Court human rights jurisdiction does not apply retrospectively to events that occurred before its adoption, and second, that the plaintiffs filed suit more than three years following the events in question and beyond the Supplementary Protocol's three-year limitations period. ${ }^{30}$ On the merits, the states again raised two arguments. First, they argued that the facts alleged in the complaint did not amount to violations of the right to the freedom of movement. The states' second and related argument was that Article 12 of the African Charter allows restrictions on free movement that are "provided for by law for the protection of national security, law and order, public health or morality." 31

In Falana v. Republic of Benin, the ECOWAS Court concluded that the plain language of the 2005 Supplementary Protocol extends the Court's jurisdiction to human rights violations that occurred

\footnotetext{
${ }^{25}$ Falana v. Republic of Benin, ECW/CCJ/APP/10/07, Judgment, para. 3 (Jan. 24, 2012) [hereinafter Falana]. ${ }^{26} \mathrm{Id}$.

${ }^{27}$ ECOWAS Free Movement Protocol, supra note _, Article 2(1) ("The Community citizens have the right to enter, reside and establish in the territory of Member States."); id. Article 3(2) ("A citizen of the Community visiting any Member State for a period not exceeding ninety (90) days shall enter the territory of that Member State through the official entry point free of visa requirements."); African Charter, supra note _, Article 12(2) ("Every individual shall have the right to leave any country including his own, and to return to his country.").

${ }^{28}$ Falana, supra note _, para. 4.

${ }^{29}$ Supplementary Protocol A/SP1/01/05 Amending the Preamble and Articles 1, 2, 9 and 30 of Protocol (A/P.1/7/91) Relating to the Community Court of Justice, Jan. 19, 2005 [hereinafter 2005 Supplementary Protocol], http://www.courtecowas.org/site2012/pdf_files/supplementary_protocol.pdf.

${ }^{30}$ Falana, supra note _, paras. 8-11.

${ }^{31}$ African Charter, supra note _, Article 12(2).
} 
prior to the Protocol's adoption. ${ }^{32}$ However, the judges limited the practical impact of that interpretation by applying the Protocol's limitations period to bar suits - such as those alleged by Falana and Moustapha-filed more than three years after the events in question occurred. ${ }^{33}$ The Court next considered whether the limitations rule should be applied to human rights suits.

Endorsing the approach adopted by a 2005 U.N. General Assembly resolution, the judges held that the limitations period applies "except in respect of gross violation of rights[,] which the violation in the instant case cannot be so characterized." 34

The Falana decision's reasoning on the latter point is somewhat ambiguous. In particular, it is uncertain whether the ECOWAS Court held that an infringement of freedom of movement is per se not a gross human rights violation, or whether the facts alleged by the plaintiffs were insufficient to prove such a violation. The judges emphasized that freedom of movement "is not absolute but qualified, that is to say the right ... though guaranteed is subject to the laws, national security, public health and morality" of the state. ${ }^{35}$ However, they also devoted an entire section of the decision to the burden of proof, concluding that "there was no restraint to the movement in Nigeria and Benin, based on the evidence of Plaintiff." 36 These statements suggest that the Court might recognize an exception to the three-year limitations period where the applicant can prove a more severe free violation of the right to freedom of movement.

Even if the latter interpretation is correct, the Court's analysis of the factual allegations in Falana is problematic in several respects. The decision begins with the unobjectionable proposition that an infringement of freedom of movement requires a showing of restraint. Yet the judges' conclusion that "there was no form of restraint" of the plaintiffs" movements is unpersuasive. ${ }^{37}$ Nothing in the facts suggests that Falana and Moustapha were impeded while traveling across Benin, but the two men claimed that they were stopped by officials at roadblocks near Nigeria's border with that country. The officials did not harass or attempt to extort money from the plaintiffs, as they allegedly did to other travelers. Nevertheless, the Court does not consider whether the unofficial roadblocks — which are all too common in West Africa despite lacking formal approval by governments, ${ }^{38}$ - violate the "provided for by law" clause of Article 12(2) of the African Charter. ${ }^{39}$

\footnotetext{
${ }^{32}$ Falana, supra note __, paras. 27-28.

${ }^{33} 2005$ Supplementary Protocol, supra note _, Article 9(3) (“Any action by or against . . any Member of the Community shall be statute barred [sic] after three (3) years from the date when the right of action arose.").
}

${ }^{34}$ Falana, supra note __, para. 30 (citing Basic Principles and Guidelines on the Right to a Remedy and Reparation for Victims of Gross Violations of International Human Rights Law and Serious Violations of International Humanitarian Law, G.A. Res. 60/147 (Dec. 16, 2005),

http://www.ohchr.org/EN/ProfessionalInterest/Pages/RemedyAndReparation.aspx. The resolution provides in relevant part: "Where so provided for in an applicable treaty or contained in other international legal obligations, statutes of limitations shall not apply to gross violations of international human rights law and serious violations of international humanitarian law which constitute crimes under international law." Id. para. 6 (emphasis added).

${ }^{35}$ Falana, supra note _, para. 33.

${ }^{36}$ Id., para. 42.

${ }^{37}$ Id., para. 33.

${ }^{38}$ Sovereignty, Supranationality and Trade, supra note __, at _. 
A similar critique applies to the analysis of the plaintiffs' detention at the Togolese border. The Court recognizes this as a restraint, but concludes that "the evidence was abundantly sufficient to the effect that the closure of the border was due to the Presidential Election and within the confines of the Protocol on free movement." Yet instead of applying the necessity and proportionality standard to evaluate the legality of closing a border during a national election - a test required by the case law interpreting Article 12(2) requires ${ }^{40}$ - the Falana decision turns to a 1985 Supplementary Protocol on Free Movement, which contains the following provision:
1. Whenever a problem of internal security shall lead to the imposition of measures restricting the implementation of the [ECOWAS Free Movement Protocol], the Member State concerned shall inform the Executive Secretariat and other Member States within a reasonable period of time.
2. Whenever, for reasons of internal security, a Member State shall deem it necessary to close its borders, the Member State concerned shall inform the Executive Secretariat, and the other Member States, if necessary even after the act, regardless of the reasons justifying such measures. ${ }^{41}$

According to the Court, these paragraphs "fortify" the conclusion that Falana and Moustapha provided "insufficient" evidence to prove a violation of the right to free of movement or to justify awarding the remedies they requested. ${ }^{42}$ The judges never indicate, however, whether Togo gave the required notice. Nor, more significantly, do they explain why it is appropriate to substitute the 1985 Protocol's self-judging approach to necessity for the more rights-protective necessity and proportionality standard of the African Charter. ${ }^{43}$ The result of this implicit conflation of the two legal standards implies a de facto diminution of freedom of movement within the sub-region.

\footnotetext{
${ }^{39}$ African Charter, supra note __, Article 12(2) (permitting restrictions on the right to leave any country only when such restrictions are "provided for by law for the protection of national security, law and order, public health or morality"); see also Modise v. Botswana, Comm. No. 97/93, African Commission on Human Rights, 14th Activity Report, para. 83 (2000-2001) ("[W]hile the decision as to who is permitted to remain in a country is a function of the competent authorities of that country, this decision should always be made according to careful and just legal procedures, and with due regard to the acceptable international norms and standards.").

${ }^{40}$ When applying the "claw-back" clauses in the African Charter, including restrictions on free movement under Article 12(2), the African Commission "weighs the impact, nature and extent of the limitation against the legitimate state interest serving a particular goal," which must be "strictly proportionate with and absolutely necessary for the advantages which are to be obtained." FRANS VILJOEN, INTERNATIONAL HUMAN RIGHTS LAW IN AFRICA 331 (2d ed. 2012). Other regional human rights tribunals apply similar standards. See, e.g., Riener v. Bulgaria, App. No. $46343 / 99$ (Eur. Ct. H.R. 2006) (evaluating the necessity and proportionality of a travel ban imposed for nonpayment of taxes). Although the ECOWAS Court applied the necessity and proportionality standard in the Balde v. Senegal case discussed below, the Court did not explain why it did not apply the same standard in the Falana decision.

${ }^{41}$ Supplementary Protocol on the Code of Conduct for the Implementation of the Protocol on Free Movement of Persons, the Right of Residence and Establishment, A/SP 2/7/85, Article 8 (July 6, 1985), quoted in Falana, supra note _, para. 43.

${ }^{42}$ Falana, supra note __, at paras. 43-44.

${ }^{43}$ The necessity standard in the 1985 Protocol allows a member state itself to determine whether closing its borders is a necessary measure. This differs from Article 12 of the African Charter, which subjects the necessity and proportionality of state restrictions on freedom of movement to review by the African Commission and Court of Human and Peoples' Rights.
} 
Whatever the shortcomings of its legal analysis, the Falana decision likely reflects the political reality in West Africa. Although mass deportation of foreigners-such Nigeria's expulsion of thousands of "illegal" workers in $1983^{44}$ — are rare, restrictions on migration remain popular, ${ }^{45}$ and member states regularly close their borders before and during national elections. ${ }^{46}$ Given this political climate, the judges' reluctance to order the removal of "all checkpoints, toll-gates, and obstacles to free movement," as the applicants requested, is understandable.

The ECOWAS Court's second free movement decision, Balde v. Republic of Senegal, ${ }^{47}$ hewed more closely to a traditional human rights analysis. The case concerned a criminal investigation of former government officials by the prosecutor of a special corruption tribunal. During pretrial proceedings, the prosecutor banned the suspects from travelling internationally. ${ }^{48}$ The officials' complained to the ECOWAS Court that the investigation violated multiple human rights, including the freedom of movement. Although the Court rejected most of the officials' allegations, it agreed that the travel ban infringed Article 12 of the African Charter.

Senegal sought to justify the travel ban under Article 12(2). Specifically, the government argued that the suspects were a threat to public order and public safety, and that the Prosecutor was authorized to issue travel ban under Article 33 of the Senegalese Code of Criminal Procedure, which provides: "The Public Prosecutor shall carry out or have carried out all the necessary measures required for investigating and trying all violations of the criminal law."49

The ECOWAS Court rejected Senegal's arguments on multiple grounds. The judges first underscored that " $[\mathrm{t}]$ he right to free movement is sanctioned by various international and regional instruments," including the African Charter. ${ }^{50}$ Turning to Article 12, the Court held that the government "failed to bring evidence" that the suspects were "disrupting public order or national security." "Even assuming for purposes of argument that a travel ban was necessary to achieve these goals, the government could only adopt such a ban "within the dictates of the law or in compliance with a court decision," and only if the ban was not "disproportionate in terms of the

\footnotetext{
${ }^{44}$ Julius Emeka Okolo, Free Movement of Persons in ECOWAS and Nigeria's Expulsion of Illegal Aliens, 40 THE WORLD TODAY 428 (Oct. 1984).

${ }^{45}$ See, e.g., Kate D.A. Costa, Nigeria: Ghana Threatens to Expel Foreign Retailers, DAILY TRUST, (June 29, 2012), http://allafrica.com/stories/201206290777.html; Good v. Botswana, Comm. No. 313/05, African Comm'n on Human Rights, 28th Activity Report, para. 205 (2009-2010) (recognizing "the challenges that are faced by African countries that might push them to resort to extreme measures like deportation in order to protect their nationals and economies from non-nationals.").

${ }^{46}$ See, e.g., Nigeria: Govt Closes Borders Ahead of Governorship Elections, DAILY INDEPENDENT (Lagos), Apr. 8, 2015, http://allafrica.com/stories/201504090252.html; Ghana closes border to Togo ahead of elections, STARR FM, Apr. 24, 2015, at http://www.ghheadlines.com/agency/starr-fm/20150424/715090/ghana-closes-border-to-togo-aheadof-elections; Umaro Djau, Authorities Close Border as Ivory Coast Election Stalls, CNN (Dec. 3, 2010), http://www.wibw.com/home/headlines/Authorities_close_border_as_Ivory_Coast_election_stalls_111265834.html.

${ }^{47}$ ECW/CCJ/APP/22/12, Judgment (Feb. 22, 2013) [hereinafter Balde].

${ }^{48}$ Id., para. 9.

${ }^{49}$ Id., para. 41.

${ }^{50}$ Id., para. 56.

${ }^{51}$ Id., paras. 58, 61.
} 
objective pursued." 52 The restriction failed both of these requirements. No provision of Senegalese law authorized the prosecutor to issue a travel ban without a court order, and the imposition of such a ban based on "mere police information" was disproportionate. ${ }^{53}$ The Court thus declared that the Senegal had violated the applicants' right to freedom of movement, and it ordered the government to "remov[e] the legally unfounded ban imposed on the Applicants, which restrains them from going outside the national territory." 54

\section{The EACJ}

Suits alleging violations of the right to free movement have a relatively prominent place on the docket of the EACJ. The Court's First Instance Division has considered three such challenges, finding violations of EAC law in two of the cases. These decisions significantly constrain the ability of governments to deny entry to the citizens of other EAC member states, to detain and expel such individuals lawfully admitted to their respective territories, and to ban international travel by their own nationals. At the same time, the Court has strictly adhered to the short two-month limitations period within which private litigants must file suit with the EACJ, barring claims that raise troubling allegations of free movement violations.

Mohochi v. Attorney General of Uganda ${ }^{55}$ is the leading precedent interpreting the EAC's free movement rules. Samwel Mohochi, a Kenyan attorney and human rights defender, traveled to Uganda in April 2011 as part of a delegation from the Kenyan chapter of the International Commission of Jurists. Immigration officials at Entebbe Airport refused to admit Mohochi into Uganda, although they permitted the rest of the delegation to enter the country. The officials sent Kenya Airways a "Notice to Return or Convey Prohibited Immigrant" and, after detaining Mohochi for several hours, placed him on an airplane to Kenya. The authorities never disclosed why they denied Mohochi entry into the Uganda, other than providing him with a copy of the Notice given to the airline. ${ }^{56}$

Mohochi promptly filed suit with the EACJ, alleging violations of free movement provisions in the EAC Treaty ${ }^{57}$ and the Common Market Protocol. ${ }^{58}$ He also claimed that he had been denied due process of law contrary to the EAC Treaty's "fundamental principles," which include "good governance[,] adherence to the principles of democracy, the rule of law, accountability, transparency, social justice, equal opportunities ... a as well as the recognition, promotion and protection of human and peoples rights in accordance with the provisions of the African Charter on

\footnotetext{
52 Id., para. 58.

${ }^{53} \mathrm{Id}$.

${ }^{54}$ Id., para. 77.

${ }^{55}$ Ref. No. 5 of 2011, EACJ First Instance Division, Judgment (May 17, 2013) [hereinafter Mohochi].

${ }^{56}$ Id. paras. 2-5.

${ }^{57}$ Treaty for the Establishment of the East African Community, Nov. 30, 1999, 2144 U.N.T.S. 255 [hereinafter EAC Treaty], Article 104 ("[The] Partner States agree . . to achieve the free movement of persons.").

${ }^{58}$ Common Market Protocol, supra note _ _, Article 7.1 ("The Partner States hereby guarantee the free movement of persons who are citizens of the other Partner States.”).
} 
Human and Peoples' Rights." 59 Finally, Mohochi asserted multiple violations of the African Charter, including "discrimination, freedom from arbitrary arrest and detention, the right to a fair and just administrative action, the right to information and freedoms of assembly, association and movement ...."60 To remedy these breaches, Mohochi asked the EACJ to declare that denying him entry without a hearing or providing "Treaty based reasons" was illegal. He also asked for a declaration that Uganda's Citizenship and Immigration Control Act, pursuant to which the government had designated him as a "prohibited immigrant," contravened the EAC laws listed above. $^{61}$

The First Instance Division initially reaffirmed prior EACJ rulings that extended the Court's jurisdiction to interpret and apply East African Community law to all provisions of the EAC Treaty and its Protocols, including the Treaty's fundamental principles clause. The First Instance judges acknowledged that the EAC's founding charter is not a "Human Rights Convention or a Human Rights Treaty as understood in international law," 62 and that the member states had not adopted the protocol referred to in the EAC Treaty to give the Court an express human rights jurisdiction. ${ }^{63}$ Nevertheless, the judges reiterated the settled EACJ doctrine that the "mere inclusion of allegations of human rights violations in a [complaint] will not deter the Court from exercising its interpretation jurisdiction ....,

Having established its authority to hear the suit, the EACJ turned to three substantive questions: whether the EAC Treaty limits Uganda's sovereignty to deny entry to nationals of other member states on security grounds; whether immigration officials were required to explain to Mohochi why they denied him entry; and whether Mohochi's arrest, detention and expulsion violated his right to freedom of movement. The Court answered each of these questions in the affirmative, finding that Uganda had breached multiple provisions of EAC law, including the human rights commitments in the Treaty's fundamental principles clause.

The reasoning and analysis in the Mohochi case are as significant as these individual holdings. The Court recognizes that Uganda, as a sovereign nation, has the "power to deny entry to . . citizens of EAC Partner States." "65 But it must exercise this power "in accordance with the law," including Community rules guaranteeing the right to freedom of movement:

\footnotetext{
${ }^{59}$ EAC Treaty, supra note _, Article 6(d); see also id. Article 7(2) ("The Partner States undertake to abide by the principles of good governance, including adherence to the principles of democracy, the rule of law, social justice and the maintenance of universally accepted standards of human rights.").

${ }^{60}$ Mohochi, supra note _, para. 9.

${ }^{61}$ Id., para. 11.

${ }^{62}$ Id., para. 28.

${ }^{63}$ Article 27.2 of the EAC Treaty provides that " $[\mathrm{t}]$ he Court shall have ... human rights and other jurisdiction as ... determined by the [EAC] Council at a suitable subsequent date. To this end, the Partner States shall conclude a protocol to operationalise the extended jurisdiction."

${ }^{64}$ Mohochi, supra note _, para. 26. For an insightful discussion of the EACJ's human rights jurisprudence, see Gathii, Missing Creep, supra note _, at 253-59.

${ }^{65}$ Mohochi, supra note _, para. 40.
} 
[B]y accepting to be bound by [the EAC Treaty and Common Market Protocol,] Uganda also accepted that her sovereignty to deny entry to persons, who are citizens of the Partner States, becomes qualified and governed by the same and, therefore, could no longer apply domestic legislation in ways that make its effects prevail over those of Community law.

Sovereignty, therefore, cannot not take away the precedence of Community law, cannot stand as a defence or justification for non[-]compliance with Treaty obligations and neither can it act to exempt, impede or restrain Uganda from ensuring that her actions and laws are in conformity with requirements of the Treaty or the Protocol. ${ }^{66}$

The Court next examined Article 7 of the Common Market Protocol, which "guarantee[s] the free movement of persons who are citizens of the other Partner States," including the visa-free entry into, free movement and residence within, and exit from the territory of other EAC member states. ${ }^{67}$ These guarantees are, however, "subject to limitations imposed by the host Partner State on grounds of public policy, public security or public health.",68

Invoking this clause, Uganda argued that its decision to exclude Mohochi was "in the best interest of [the country's] national security," and furthered the "security interest of the people of the [EAC]." "69 The First Instance Division was unpersuaded. Uganda never explained how Mohochi posed a security risk; instead it merely "asserted that the Court should consider the circumstances during the wind of terrorism." "70 Indeed, no "allegation of wrongdoing [was] levelled against" Mohochi during his detention, and allowing him "just be left to await the next flight" without arresting or charging him suggested that he was "known to be harmless." 71 Uganda also failed to notify the other EAC member states of the limitation on free movement, as the Common Market Protocol requires. ${ }^{72}$ In sum, the government provided no evidence that the "Applicant indeed constituted a real threat to regional security."73

The EACJ also concluded that Ugandan officials were required to explain to Mohochi the basis for his exclusion and to provide him an opportunity to challenge that decision. According to the Court, the EAC Treaty's fundamental principles clause includes an obligation to provide "due process" to

\footnotetext{
${ }^{66}$ Id., paras. 52-53.

${ }^{67}$ Common Market Protocol, supra note __, Article 7.2.

${ }^{68}$ Id., Article 7.5.

${ }^{69}$ Mohochi, supra note _, paras. 15-16.

${ }^{70}$ Id., para. 96 (emphasis in original).

${ }^{71}$ Id., para. 98, 100.

${ }^{72}$ Common Market Protocol, supra note __, Article 7.6 (“A Partner State imposing a limitation under paragraph 5, shall notify the other Party States accordingly."). The EACJ described notification as "meant for the public in the Partner States to be known and be complied with by all." Mohochi, supra note _, para. 114.

${ }^{73}$ Mohochi, supra note _, para. 115. The EACJ does not explain the quantum of evidence required to justify a security exception to free movement, other than explaining that "[a] Partner State, before imposing a limitation on an individual would have to satisfy itself that the measure is merited in each particular case." Id.
} 
individuals denied entry into a member state's territory. ${ }^{74}$ Such process requires "notice and the right to a fair hearing before a tribunal."75 Uganda was thus under "a duty to give [Mohochi] sufficient reasons for denying him entry, declaring him a prohibited immigrant and removing him from Uganda." They also "had a duty to afford him a fair opportunity to be heard, and, as they made their decisions about him, to take into consideration whatever he had to say." "76 The government breached these duties and instead "resorted to kangaroo methods for want of a lawful procedure by which to swiftly return the Applicant to Kenya."77

Finally, the First Instance Division found that Ugandan immigration officials had violated Mohochi's right to freedom of movement. "It is undeniable, that [the Applicant] was taken into custody, deprived of his liberty and was not a free man between 9am and 3pm." 78 In holding this conduct to be illegal, the EACJ underscored the connection between human rights and free movement and their importance to the East African integration project.

Detention is indeed deprivation of liberty. When it is illegal it is not only an infringement of the freedom of movement, but also an act that undermines one's dignity. Furthermore, when a citizen of a Partner State is illegally detained in another Partner State, with no right to be informed why or to be heard in his defence, and the reasons cannot be disclosed, even in a court of law, it is not just a violation of the Treaty, it is indeed a threat to integration. ${ }^{79}$

The Court concluded by granting all of Mohochi's requests for declaratory relief, including a declaration that Uganda's Citizenship and Immigration Control Act was "rendered inoperative and have no force of law" to the extent that the Act conflicts with EAC free movement rules. ${ }^{80}$

The EACJ's ringing endorsement of freedom of movement in the Mohochi case is all the more striking in light of the ongoing terrorist attacks by Muslim extremists in East Africa-a backdrop only hinted at in the decision itself. On July 11, 2010, the terrorist group Al-Shabaab claimed responsibility for two bombings in Kampala that killed 74 people. ${ }^{81}$ Soon after the attacks, Ugandan officials arrested twelve Muslim suspects from Kenya. They later detained Al-Amin Kimathi, a Muslim human rights advocate from Kenya and the suspects' legal counsel, during a

\footnotetext{
${ }^{74}$ Id., paras. 69-72. The due process requirement appears to be based on the "good governance" and "rule of law" provisions in Articles 6(d) and 7(2) of the EAC Treaty.

${ }^{75}$ Id., para. 72 (quoting Due Process, BLACK's LAW DiCTIONARY (9th ed. 2009).

${ }^{76}$ Id., para. 76. The EACJ supported this conclusion with a quote from a ruling of the European Court of Justice: "[A] decision ordering the deportation of a Community alien may not be carried out, save in cases of urgency which have been properly justified, against a person protected by Community law until the latter has been able to exhaust the remedies guaranteed by Articles 8 and 9 of Directive 64/221.” Id., para. 75 (quoting State v. Royer, Case 48/75 [1976] E.C.R. I-497).

${ }^{77}$ Id., para. 95.

${ }^{78}$ Id., para. 105.

${ }^{79}$ Id., para. 108.

${ }^{80}$ Id., para. 130.

${ }^{81}$ Josh Kron, Bombers Kill More Than 50 in Attacks in Uganda, THE NEW YORK TIMES (July 11, 2010), http://www.nytimes.com/2010/07/12/world/africa/12uganda.html; see also Uganda Bomb Blast Kills At Least 74, THE GUARDIAN (July 11, 2010) http://www.theguardian.com/world/2010/jul/12/uganda-kampala-bombs-explosions-attacks
} 
visit to Uganda for a hearing in the case in September 2010. ${ }^{82}$ Mohochi belonged to several human rights organizations that publicly condemned Kimathi's detention. Other individuals affiliated with these groups were denied entry into Uganda. ${ }^{83}$ This suggests that the government may have targeted Mohochi for exclusion because of his involvement in the campaign to free Kimathi. ${ }^{84}$

These same events triggered a second EACJ free movement suit by another Kenyan human rights attorney, Mbugua Mureithi Wa Nyambura, who, together with Kimathi, represented several suspects charged in the Kampala bombings. ${ }^{85}$ Unlike Mohochi, Nyambura was permitted entry into Uganda. But only a few hours later he was arrested at gunpoint, harassed, imprisoned with his clients for two days, and then expelled from the country without explanation. ${ }^{86}$ Also unlike Mohochi, Nyambura did not file suit with the EACJ for more than fourteen months after these events — well beyond the two-month limitations period specified in the EAC Treaty. ${ }^{87}$

The First Instance Division applied settled EACJ case law requiring the dismissal of suits filed outside the limitations period. Nyambura sought to excuse the delay by arguing that "he wanted to be told before he initiated [the case] when, where, why, and by whom he had been detained." 88 The judges categorically rejected this argument, citing the allegations in the complaint to show that Nyambura was aware of all information needed to file suit after his expulsion from Uganda. They also quoted from an earlier decision of EACJ Appellate Division, Attorney General of Uganda v. Omar, which held that " $[\mathrm{t}]$ he principle of legal certainty requires strict application of" the

\footnotetext{
${ }^{82}$ See Xan Rice, Kenyan Activist Becomes A Victim of Rendition, Time, (Mar. 10, 2011), http://content.time.com/time/world/article/0,8599,2057966,00.html (noting that Al-Amin Kimathi was detained on September 15 2010); see also Lillian Onyango, Kenya: Govt Ignoring Muslims, Say Rights Groups, DaILY NATION (Apr. 15, 2011) [hereinafter Onyango, Govt. Ignoring Muslims], http://allafrica.com.proxy.lib.duke.edu/stories/201104180002.html.

${ }^{83}$ See Freedom for Activist Charged With Uganda Bombing, AMNESTY INT’L (Sept. 12, 2011), https://www.amnesty.org/press-releases/2011/09/freedom-activist-charged-uganda-bombing/ (noting that the Ugandan government denied entry to and deported "several human rights activities and lawyers who travelled to Uganda to monitor the case against Al-Amin Kimathi."); Maxwell Masava, Kenya: Privy to Kimathi Detention. Says Jurists, THE STAR (Apr. 16, 2011), http://allafrica.com.proxy.lib.duke.edu/stories/201104180624.html (recognizing that Uganda denied entry to other attorneys associated with Muslim human rights organizations).

${ }^{84}$ See Lillian Onyango, Govt. Ignoring Muslims, http://allafrica.com.proxy.lib.duke.edu/stories/201104180002.html (stating that four human rights activists were denied entry into Uganda in April 2011 despite an appointment with Ugandan Chief Justice). A Ugandan court dismissed the charges against Kimathi in September 2011, after he spent almost a year in detention. Uganda: Charges Against Human Rights Defender Dropped, IFEX (Sept. 13, 2011), https://www.ifex.org/uganda/2011/09/13/kimathi_released/.

${ }^{85}$ Nyambura v. Attorney Gen. of Uganda, Ref. No. 11 of 2011, EACJ First Instance Division, Judgment (Feb. 24, 2014) [hereinafter Nyambura].

${ }^{86}$ Id., para. 4.

${ }^{87}$ EAC Treaty, supra note _, Article 27.2 ("The proceedings provided for in this Article shall be instituted within two months of the enactment, publication, directive, decision or action complained of, or in the absence thereof, of the day in which it came to the knowledge of the complainant, as the case may be.").

${ }^{88}$ Nyambura, supra note _, at 18.
} 
limitations period, and that the EAC Treaty does not "provide any power to the Court to extend, to condone, to waive or to modify the prescribed time limit for any reason." 89

The rigid adherence to the two-month limitations rule in the Omar case was the Appellate Division's response to entreaties from private litigants, who had argued that the EACJ should adopt exceptions to the limitations rule similar to those recognized by international human rights courts and review bodies. ${ }^{90}$ In several earlier rulings, the First Instance Division had applied such exceptions to entertain suits filed after the limitations period expired. The Appellate Division in Omar rejected this more lenient approach, emphasizing

the critical difference between the EAC Treaty (which governs trade matters as the objective of cooperation between Partner States) on the one hand; and, on the other hand, Human Rights Conventions and Treaties which provide "exceptions" (for continuing violations) on the grounds that securing the fundamental rights of the citizens is of paramount essence. For this reason, the Judicial Bodies that have Human Rights jurisdiction must strenuously uphold and protect all such rights through a liberal and purposive interpretation. ${ }^{91}$

In contrast, the EACJ's paramount goal is to "balance the interest of the individual complainant against the collective interests" of Community citizens and institutions "in ensuring legal certainty in the efficient and effective operation of the affairs of the Community." "92 Stated more pointedly, the Appellate Division views the EACJ an unusual legal creature - an international judicial body that primarily adjudicates human rights claims even as it publicly disclaims an identity as an international human rights court. ${ }^{93}$

Seen from this perspective, the EACJ's most recent free movement decision is noteworthy. The case, East Africa Law Society v. Attorney General of Burundi, concerned a challenge to the prosecution and disbarment of Isidore Rufyikiri, the President of the Bar Association of Burundi, in response to allegations of corruption. ${ }^{94}$ The free movement issues in the case related to an order by the Public Prosecutor prohibiting Rufyikiri from traveling outside the country. ${ }^{95}$ The East Africa Law Society, the nominal plaintiff, challenged the order as contrary to the EAC Treaty's fundamental principles. The First Instance Division agreed, holding that Burundian law requires an order from a court to bar an individual from traveling abroad. The prosecutor never sought such an order. As a result, the EACJ held that "due process of law, one of the cornerstones of the rule of

\footnotetext{
${ }^{89}$ Id. at 20 (quoting Attorney Gen. of Uganda v. Omar, App. No. 2 of 2012 (arising out of Ref. No. 4 of 2011), Appellate Division, Judgment, para. 59 (Apr. 15, 2013) [hereinafter Omar]).

${ }^{90}$ Gathii, Missing Creep, supra note at 272 .

91 Omar, supra note _, para. 48.

92 Id., paras. 51-52.

${ }^{93}$ James Thuo Gathii, The Variation in the Use of SubRegional Integration Courts between Business and Human Rights Actors: The Case of the East African Court of Justice, 79 L. \& CONTEMP. PROBS. [hereinafter Gathii, Variation in Use].

${ }^{94}$ Ref. No. 1 of 2014, EACJ First Instance Division, Judgment (May 15, 2015) [hereinafter Rufyikiri].

${ }^{95}$ Id., paras. 93-96.
} 
law, was not respected . . . and that this constitutes a violation of . . Articles 6(d) and 7(2) of the Treaty." 96

Two aspects of the decision are significant. First, Rufyikiri did not allege violations of the Community's free movement guarantees, perhaps because those provisions focus on each state's obligations to the nationals of other member nations, not on the duties that a government owes to its own citizens. ${ }^{97}$ By framing the challenge to the travel ban as a breach of the EAC Treaty's fundamental principles, the applicant provided an opportunity for the First Instance Division to extend the due process analysis in Mohochi-involving restrictions on a foreign national's ability to enter a country-to restrictions on the freedom of a citizen to leave his or her own country.

Second, human rights discourse is conspicuously absent. Whereas both the Mohochi and Nyambura cases alleged violations of multiple rights in the African Charter (as well as breaches of EAC law), such claims do not appear in Rufyikiri, although the facts in the complaint could easily have been reframed in human rights terms. Instead, the East Africa Law Society challenged the prosecutor's manifest failure to follow Burundian law as violation of due process, a legal principle that international human rights law also recognizes. This framing suggests that advocates are becoming more comfortable with the EACJ's preference for adjudicating human rights issues in practice but not in name.

\section{The Insights of THE Free Movement CASES For Sub-REgional Human Rights LiTigation in AFrica}

The free movement jurisprudence of the SADC Tribunal, ECOWAS Court and EACJ offer a number of insights for how sub-regional judges in Africa regulate access to the courts, interpret international law, and award remedies to prevailing litigants. This Part compares and contrasts the approaches of the free movement case law for each of these key issues, supplemented by references to other recent decisions and scholarship. It highlights similarities and differences among the three courts' approaches and offers explanations for these patterns.

\section{A. Access}

The overarching issue that determines private litigant access to the African sub-regional courts is how strictly judges construe black letter admissibility requirements, such as exhaustion of local remedies, limitations periods and standing rules. Although exhaustion is a foundational element of all three regional human rights systems and of U.N. treaty bodies, it was deliberately omitted from the legal instruments establishing the EACJ and the ECOWAS Court. The SADC Tribunal Protocol does require exhaustion, although in the Campbell case the Tribunal recognized the exceptions to exhaustion adopted by other judicial and quasi-judicial human rights bodies. ${ }^{98}$

\footnotetext{
${ }^{96}$ Id., para. 96.

${ }^{97}$ E.g., Common Market Protocol, supra note _, Article 7.1 ("The Partner States hereby guarantee the free movement of persons who are citizens of the other Partner States") (emphasis added).

${ }^{98}$ Campbell, supra note _, paras. 25-31 (interpreting Article 15.2 of the SADC Tribunal Protocol).
} 
In the Cimexpan free movement suit, the SADC judges faced a different issue. The applicant made no attempt to seek relief from domestic courts, administrative agencies or executive officials following his expulsion from Tanzania. It was thus plain that the Tribunal could not apply an exception to the exhaustion requirement. The judges nevertheless carefully explained what the applicant could have done to satisfy the Tribunal's admissibility rule. Even more importantly, the judges chose to address the merits of the case. Although the facts in Cimexpan revealed no violation of the applicant's rights, the judges' careful treatment of the admissibility and merits of the suit signaled to future litigants both how to access the Tribunal as well as the kinds of human rights claims that would likely receive a sympathetic hearing.

The ECOWAS Court in the Falana case also broadcast a signal to future litigants - although the message was quite different. Since its very first case, the Court has eschewed opportunities to adopt expansive or novel interpretations of international human rights law. Yet, when applicants present well-supported allegations of established human rights, such slavery, torture, arbitrary detention - and, in the Balde case, freedom of movement - the Court has not shied away from issuing bold judgments against national governments. ${ }^{99}$ The judge-made exception to the three-year limitations period recognized in Falana is consistent with this approach. Going forward, the exception will screen out stale complaints alleging less serious violations of individual rights while giving ECOWAS judges leeway to determine which abuses qualify as gross violations that can be reviewed on the merits even if they were not timely filed.

In contrast to their West African colleagues, EACJ judges have refused to imply exceptions to the EAC's limitations period. The judges are surely aware - not least the because many continue to serve as national judges in their home countries during their part-time appointments to the $\mathrm{EACJ}^{100}$ —of the many barriers that impede individuals from going to court, including understanding their legal rights, determining whether those rights have been violated, gathering facts and evidence, and finding suitable counsel to represent them. Why, then, would the judges refuse to recognize any exceptions to the very short two-month window during which litigants must perform all of these difficult tasks?

The short answer is that a shortened limitations period was part of the backlash against the EACJ following its controversial rulings in the Nyong'o case. ${ }^{101}$ By amending the EAC Treaty to narrow the Court's authority in various ways, the member states laid down a series of red lines that the judges have been loath to cross. Doing so preserves the EACJ's independence to interpret the Treaty and other EAC rules in cases that are properly before it. Strict adherence to the limitations period also privileges attorneys, such as the East Africa Law Society, who are repeat players in human rights litigation before the Court and are familiar with its procedural restrictions. But this strict approach to limitations may also hamper the EACJ's ability to cultivate a broader set of

\footnotetext{
${ }^{99}$ See Alter, Helfer \& McAllister, supra note __, at 765-66 (reviewing ECOWAS Court jurisprudence).

${ }^{100}$ Gathii, Mission Creep, supra note _, at 273.

${ }^{101}$ For a discussion of the Nyong'o litigation and the backlash that ensued, see Alter, Gathii and Helfer, supra note __. at
} 
supporters to file complaints challenging other violations of EAC law and to push governments to comply with the court's rulings. ${ }^{102}$

\section{B. Interpretation}

Sub-regional courts in West, East and Southern Africa have adopted differing interpretations of the Community and human rights instruments that protect freedom of movement. Although the small number of cases decided to date precludes drawing any definitive conclusions, there are a few plausible explanations for the courts' divergent interpretive approaches in these cases.

First, the rules governing the free movement of persons vary significantly across the three subregions. The rules are weakest in SADC, which, as noted above, recognizes free movement as only an aspirational goal pending the entry into force of an anemic protocol on that topic. Free movement is somewhat more strongly protected in ECOWAS, which has adopted a blueprint to expand free movement rules in a series of progressively broader protocols. The EAC has the most expansive free movement rules. Its Common Market Protocol guarantees free movement for all individuals, including workers and their families, adopts a program to harmonize identity documents and labor policies, and recognizes the rights of residence and establishment for nonnationals. ${ }^{103}$ Seen from this perspective, it is hardly surprisingly that the EACJ, in the Mohochi and Rufyikiri decisions, provided the most robust interpretation of sub-regional free movement rules. And it is equally apparent why neither the applicant nor the judges in the Cimexpan case so much as mentioned a Community right to free movement in a suit challenging the expulsion of a national of one SDAC member state by another member state.

A second factor that illuminates the differing interpretations is the scope of each court's subject matter jurisdiction. The SADC Tribunal Protocol is the most capacious of the international instruments establishing the three courts. The Protocol gives the Tribunal broad authority to "develop its own Community jurisprudence having regard to applicable treaties, general principles, and rules of public international law . ..."104 In the Campbell case, SADC judges held that this clause "settles the question whether the Tribunal can look elsewhere to find answers where it appears that the Treaty is silent." 105 The Protocol's expansive mandate may explain why the judges in Cimexpan did not shy away from endorsing aspirational international norms (i.e. soft law) and scholarly writings urging recognition of minimum human rights protections for foreign nationals.

Turning to West Africa, the 2005 Supplementary Protocol gives the ECOWAS Court express authority to review human rights suits filed by individuals. The Protocol does not, however, define which human rights the judges may apply, nor, more significantly, does it grant the Court jurisdiction over private litigant suits alleging violations of the ECOWAS Treaty, its Protocols, or other Community rules. Although the Court can interpret and apply these legal instruments in suits

\footnotetext{
${ }^{102}$ See Gathii, Variation in Use, supra note _, at _..

${ }^{103}$ Common Market Protocol, supra note __, Articles 7-14.

${ }^{104}$ SADC Tribunal Protocol, supra note __, Article 21(b).

${ }^{105}$ Campbell, supra note _, para. 34.
} 
between member states or between a member state and a Community institution, no such case has ever been filed. ${ }^{106}$

The bifurcation of the ECOWAS Court's jurisdiction sits uneasily with the dual protection of free movement in both the African Charter and in ECOWAS protocols. It suggests that whether the judges hear a case depends on whether private litigants frame their complaints as human rights violations rather than breaches of sub-regional free movement rules - even if the facts underlying those complaints are identical. The bifurcation of the Court's jurisdiction may also explain the contrasting interpretative approaches in the Falana and Balde cases. The former suit, which challenged formal and unofficial barriers to travel across West Africa, was framed primarily as a breach of ECOWAS free movement rules; the latter, involving a ban on all foreign travel applied to a state's own citizens, was litigated exclusively on human rights grounds.

The EACJ's jurisdictional mandate cuts in the opposite direction. The EAC Treaty provides East African judges with unequivocal authority to interpret all aspects of Community law. In contrast, the judges' power to entertain human rights suits is more tenuous and continues to be challenged by governments. The Court has justified its jurisdiction over such suits by citing the references to human rights in the Treaty's fundamental principles clause. Yet as the Appellate Division's Omar judgment reveals, the EACJ has refrained from adopting the pro-applicant doctrinal innovations that regional human rights tribunals have embraced because it lacks an express human rights mandate. In cases alleging violations of the right to freedom of movement, however, there is less need for such caution due to the robust protections of that right in EAC law. The result is that EACJ judges have adopted bold legal rulings that forcefully condemn arbitrary restrictions on entering or leaving a member state and that label such restrictions as a dual threat — to individual liberty and to subregional integration.

\section{Remedies}

The relief that international courts provide to prevailing litigants depend on a range of factors, including the kinds of remedies the court is authorized to award, nature and extent of the applicant's injuries, and the judges' (often unarticulated) sense of whether the defendant — usually a state or government actor - is likely to comply with the court's orders. As this last factor suggests, remedies enable international judges to modulate the political impact of their rulings, including decisions that expansively interpret substantive rules or judicial access provisions. A state that loses a case but need not do much to comply with the judgment against it is, all other things equal, less likely to challenge that judgment or incite a backlash against the judges that issued the decision.

The most common remedy requested by the applicants in the sub-regional free movement cases was a declaration that the travel restrictions infringed human rights law and/or Community law. The ECOWAS Court and EACJ, the two courts that ruled in favor of the applicants, readily granted declaratory relief. ${ }^{107}$ But the judges went further. In Balde, the ECOWAS Court ordered Senegal

\footnotetext{
${ }^{106}$ See Alter, Helfer \& McAllister, supra note __, at 757-58.

${ }^{107}$ As explained above, in Cimexpan the SADC Tribunal dismissed an application challenging a Tanzanian deportation order that included a request to rescind the order. The dismissal mooted the request. In the Campbell litigation filed by
} 
to remove the travel ban. ${ }^{108}$ And in Mohochi, the EACJ issued an order asserting that the offending Ugandan legislation was "rendered inoperative and ha[d] no force of law" to the extent that the statute conflicted with the EAC Treaty and Protocols. ${ }^{109}$ Whereas the former remedy applies only to a single individual, the latter has a much wider legal and political impact.

The EACJ's bolder remedial order is consistent with its capacious interpretation of East Africa's more advanced free movement rules, discussed above. The Court did not, however, grant all of the relief that the applicant requested. Its declaratory orders were more temperate in tone than those Mohochi had sought. The judges also emphasized that Uganda's Citizenship and Immigration Control Act remains applicable "where citizens of other nations, except the Partner States, are concerned." 110 Finally, the EACJ declined to award costs to Mohochi because he had filed suit "to highlight, contest and cause resolution to an issue of regional concern rather than to seek material restitution ... from the Republic of Uganda."111 Due to the "public interest" nature of the litigation, which would "enrich and benefit Community jurisprudence," the case was "a fitting one where each party should bear their costs.",112

In contrast to their colleagues in East Africa, the ECOWAS judges in Balde avoided invalidating a domestic statute by construing Senegalese law as requiring a court to issue a travel ban. This interpretation seems entirely reasonable. But it is also consistent with the ECOWAS Court's cautious approach to remedies in other high profile cases, which favor modest damage awards and declarations of violations over injunctions and orders striking down national legislation. ${ }^{113}$

\section{CONCLUSION}

The free movement case law of the SADC Tribunal, ECOWAS Court and EACJ illustrate some of the challenges faced by international judicial bodies that adjudicate human rights cases but were not initially established to hear such suits. The discrepancy between the courts' originally intended functions and their actual practice helps to explain the different reasoning and results of the free movement decisions. That mismatch also suggests that the sub-regional courts are likely to chart courses that diverge from the relatively expansive approaches to access, interpretation and remedies adopted by the human rights tribunals in Africa, the Americas and Europe.

There are three plausible explanations for this divergence which offer fruitful areas for future research. First, the courts in West, East, and Southern Africa operate at the interface of

\footnotetext{
white farmers in Zimbabwe, SADC judges awarded expansive remedies that included damages, injunctive relief and, eventually, contempt orders against the state for ignoring the Tribunal's rulings. See Alter, Gathii and Helfer, supra note _, at _. 
international human rights law and sub-regional integration law, an intersection that colors their approach to adjudication in distinctive ways. Second, the access rules, interpretive authority and remedial powers of the three courts are less a product of rational design than the result of evolving, piecemeal and sometimes conflicting decisions by governments whose support for sub-regional integration - and for the role of international judges in the integration process - waxes and wanes over time. Third, all three courts have experienced significant political backlashes during their early years. The outcomes of these backlashes varied, but each has left an indelible mark on subregional judges, in particular on how bold or timid they are in their still-evolving approaches to access, interpretation and remedies.

Author(s): Laurence R. Helfer

Title: Sub-regional Courts in Africa: Litigating the Hybrid Right to Freedom of Movement

iCourts Working Paper, No. 32, 2015

Publication date: 1/September/2015

URL: http://jura.ku.dk/icourts/working-papers/

(c) Author

iCourts Working Paper Series

ISSN: 2246-4891

Laurence R. Helfer, Professor of Law, Duke University, United States of America

E-mail: helfer@law.duke.edu 
The iCourts Online Working Paper Series publishes pre-print manuscripts on international courts, their role in a globalising legal order, and their impact on politics and society and takes an explicit interdisciplinary perspective.

Papers are available at http://jura.ku.dk/icourts/

iCourts

- The Danish National Research Foundation's Centre of Excellence for International Courts The Faculty of Law University of Copenhagen

Studiestraede 6

DK-1455 Copenhagen K

E-mail: icourts@jur.ku.dk

Tel. +4535322626 